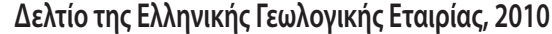

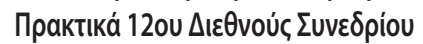

Пátpa, Máıoc 2010
Bulletin of the Geological Society of Greece, 2010

Proceedings of the 12 th International Congress

Patras, May, 2010

\title{
METHODOLOGY FOR OPTIMAL DETERMINATION OF NEW DRILLING PROGRAM IN AN ACTIVE OPEN PIT: EXAMPLE FROM AN ACTIVE SULFATE OPEN PIT IN ALTSI, LASITHI PREFECTURE, EASTERN CRETE
}

\author{
Manoutsoglou E. ${ }^{1}$, Panagopoulos G. ${ }^{1}$, Spyridonos E. ${ }^{2}$ and Georgiou A. ${ }^{3}$ \\ ${ }^{1}$ Technical University of Crete, Department of Mineral Resources Engineering, Research Unit of Geology, \\ 73100 Chania,Greece,emanout@mred.tuc.gr,gpanag@mred.tuc.gr \\ ${ }^{2}$ National and Kapodistrian University of Athens, Faculty of Geology and Geoenvironment, \\ vangelis@zedat.fu-berlin.de \\ ${ }_{3}^{3}$ TITANCement S.A.,egeorgiou@titan.gr
}

\begin{abstract}
For the cement industry the minerals gypsum and anhydrite, due to their similar chemical composition, are of the same importance. In cement production line, the energy requirements for grinding anhydrite are different from that of gypsum. Occasionally, the difference in mechanical properties of the extreme members (anhydride / stiff - gypsum / brittle) can cause problems during grinding procedure. For these reasons it is necessary to be aware of the spatial distribution of these rocks in an active open pit. This knowledge, because of its strict connection with the calculation of the reserves (geological and recoverable), contributes to the direct production planning of the open pit and to the medium and long term planning as well. In order to approach the spatial distribution of sulphate rocks in the active gypsum open pit of INTERBETON S.A. in Altsi (Sitia region, Eastern Crete), new exploration boreholes were drilled. The proposed methodology concerning the determination of the new borehole locations consists of two steps. In the first step detailed geological mapping of the surface sulphate rocks is conducted and in the second step a three-dimensional geological model is constructed. The model's construction is based on data derived from a past drilling program. Those data were enriched with the results of geochemical analysis of 100 new surface samples. The surface samples were taken by means of Wagon Drill accordingly to a predefined grid. Five different drilling scenarios were proposed, contributing to the determination of the optimal drilling program.
\end{abstract}

Key words: 3D Geological Modelling, Active Open Pit, Sulfate Deposits, Optimal Drilling Program.

\section{Introduction}

In cement industry, calcium sulfate (either in the form of gypsum or anhydrite), is one of the ingredients of Portland cement which increases the time needed for the setting of cement. But, the difference in stiffness of anhydride and gypsum can cause problems in crushing and grinding procedure in the open pit. The stiffness of Anhydrite is 3-3.5 in Mohs scale, while for gypsum it is 1.5-2. It is known that gypsum is dehydrated and is transformed to anhydrite as a consequence of geological burial. On the contrary, anhydrite is transformed to gypsum when it comes in contact with fluids during exhumation. These two minerals, are common minerals in evaporitic sequences. Evaporites are 
deposits which are created by salt precipitation from aqueous solutions during solar evaporization. The precipitation begins when the aqueous solution's salt concentration exceeds $50 \%$ (brine). If the brine is saturated in $\mathrm{SO}_{4}{ }^{-2}$ and $\mathrm{Ca}^{+2}$ gypsum or anhydrite is formed. These two forms of calcium sulfate usually transit to each other (Warren, 2006).

The knowledge of the quantitative spatial distribution of these two extreme members is essential both for the immediate and the long term programming of the development of the active gypsum open pit in Altsi, Eastern Crete, where INTERBETON S.A. operates. In this study the combination of several methodologies aiming to the determination of the new exploration drilling program in the active open pit is presented. The results of this drilling program are substantial for the accomplishment of the objective.

\section{Geological setting}

Permian/Triassic evaporites form almost 35\% of the global evaporite deposits. In that period palaeogeography and climate produced favourable circumstances for evaporite formation, which reached a peak during Triassic. After the formation of Pangea and the drop of sea level, the marginal basins became shallower and a large number of endocratonic basins were created. During Permian, the climate became even more arid, contributing to the increase of evaporation's rate (Trappe, 2000). Evaporites of Extrenal Hellinides comprise a part of the Permian/Triassic evaporitic layers which were formed around Pangea. Evaporites are regarded as the first Alpine deposits of Paxos and Ionian isopic zones. This conclusion is based on field observations, compounded with existing drilling data. Their age is Permian/Triassic, but there are observations of evaporitic intercalations within limestones of lower Liasic and Cretaceous age, as well. Their maximum thickness varies from $1500 \mathrm{~m}$ to $3000 \mathrm{~m}$ (Nikolaou, 1986).

The island of Crete exhibits several sulfate outcrops. Many of them were characterized as exploitable deposits and some are still regarded as significant deposits both quantitative and qualitative. Those deposits are discriminated according to their time of genesis in Permian/Triassic and Neogene. The main characteristic of Neogene deposits is the exclusive existence of dihydrate form of calcium sulphate $\left(\mathrm{CaSO}_{4} \cdot 2 \mathrm{H}_{2} \mathrm{O}\right)$ related to the "salinity crisis" or "Messinian event", which affected the whole Mediterranean area during Messinian. (Kanaris, 1989). On the contrary, Permian/Triassic deposits exhibit the two main forms of calcium sulfate: gypsum $\left(\mathrm{CaSO}_{4} \cdot 2 \mathrm{H}_{2} \mathrm{O}\right)$ and anhydrite $\left(\mathrm{CaSO}_{4}\right)$ (Raulin,1869; Cayeux,1902; Papastamatiou, 1958; Fytrolakis, 1980; Antoniou, 1987). Deposits of Permian/Triassic age are all over the island. One of the most significant is that of Altsi in Eastern Crete. Its extent is $1.25 \mathrm{~km}^{2}$ and is an exploitable mineral resource. It is placed above the lower layers of the metamorphic Phyllitic Nappe and it is surrounded by multi-folded schists, which belong to the same nappe, and by younger sediments as well (Kanaris, 1989).

\section{Methods}

The methodologies followed include field and computational work. In the first stage of our study, all existing data were digitized in order to construct a preliminary three dimensional model of the sulfate deposits of the open pit. Planning of the field works was based on this preliminary 3D model. Results of geological mapping of the open pit's slopes (scale 1:500) and the petrographical study of representative sulfate samples were integrated into the 3D model. Finally, the model was used to formulate alternative scenarios for exploration drilling programs. The aim of this work was to achieve maximum information about the spatial distribution of gypsum and anhydrite in the quarry, while minimizing the cost of the drilling program. 


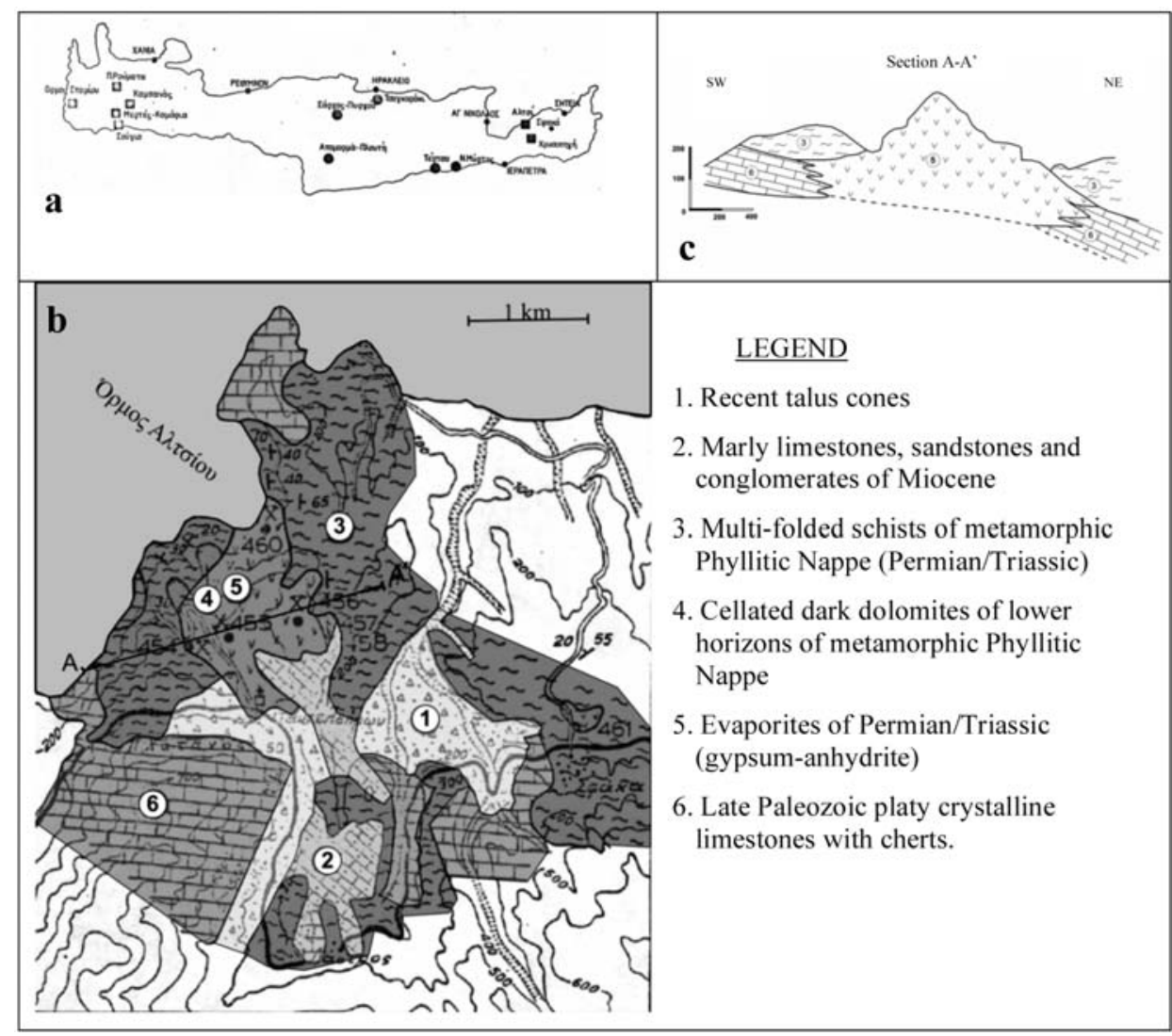

Fig. 1: (left): a) Deposits of Permian/Triassic age (squares) and Neogene age (circles) in Crete island. b), c) Geological map and section of the area where gypsum-anhydrite deposit is located. (after Kanaris, 1989).

\subsection{Geological mapping}

During geological mapping in scale 1:500, all the geological features observed on the pit's slopes were mapped. According to this mapping, the sulfate deposit of Altsi consists of seven different lithological units. These units are the schists of the bedrock, the light-colored sulfates with dolomitic segments, the light-colored sulfates with dark laminas, the dolomites, the anhydrites, the soft gypsums and the stiff gypsums.

In particular, the light grey sulfates host dark dolomitic fragments of centimeters in size. The lightcolored sulfates with dark laminas are white to white ash with dark to light grey laminas. The mineralogical composition of laminas can be either dolomitic or magnesitic or even sulfate. The soft gypsum is white to white ash without any calcitic inclusion. All the above three units are brittle, while the white to white ash coarse crystalline gypsum is rather massive. The hardest sulfate unit is anhydrite. It is coarse crystalline dark grey and often contains dolomitic fragments. The dark dolomites are always observed in the open pit area as fragments of centimeter to meter in size, which are hosted in sulfate formations and never as a distinct layer. The schists belong to Phyllite Nappe (after Dornsiepen et al., 2001) and surround all the aforementioned units. The schists present reddish colour close to their contact with the sulphate deposit. 


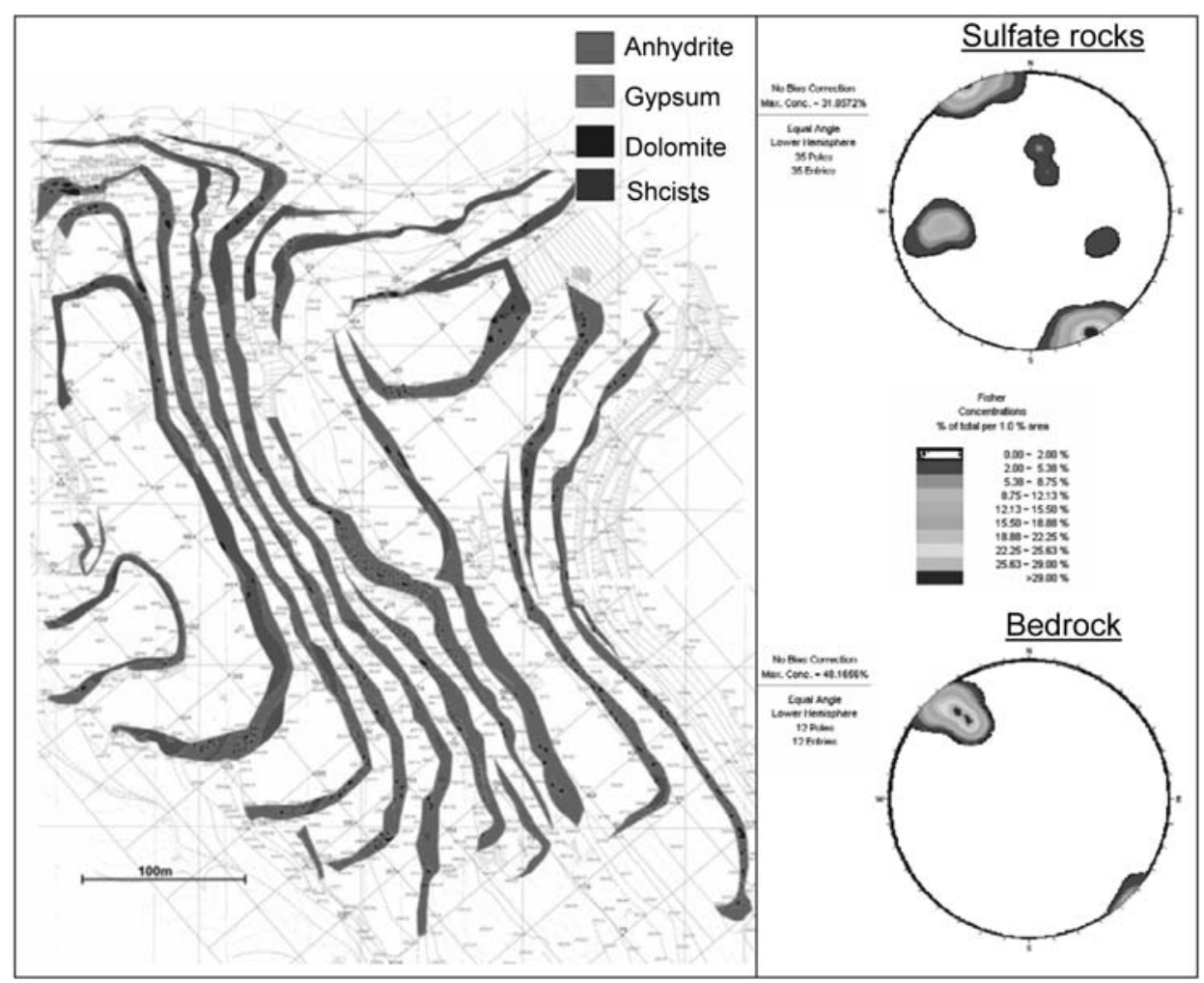

Fig. 2: Geological map of the pit area which depicts the four lithological units. It is also shown two stereonets concerning fault planes' orientation both in the sulphate rocks and the bedrock.

Initially, these units were separated by their macroscopic characteristics. Later, representative samples were taken from each lithological unit and were analyzed geochemically. Lithological units that had similar mineralogical composition were grouped in order to simplify the geological map. This fact resulted in the generation of a new geological map (Fig. 2) distinguishing four lithological units. These are gypsum, anhydrite, dolomite and schist.

The geological map of Figure 2 shows the surface distribution of gypsum and anhydrite on the slopes of the open pit. It is concluded that gypsum outcrops cover the larger area of the pit, while anhydrite outcrops exist in the northern and western part. The dolomitic segments are dispersed throughout the open pit, having size of centimeter to meter. The size and the frequency in appearance of dolomitic segments increase towards the upper levels of the eastern part. The bedrock is observed in the lower level of the pit.

In order to understand the structural regime of the area where the open pit is located, fault planes' orientation measurements were conducted in both the sulfate deposits of the pit and the bedrock. In figure 2 are shown the two major tectonic systems. The first one has an ENE-WSW orientation with almost vertical dip $\left(85^{\circ}-90^{\circ}\right)$ which is observed in both the sulfate rocks and the bedrock. The second one has an NNW-SSE orientation with $65^{\circ}$ dipping angle towards the WSW occurring only in the sulfate rocks. 


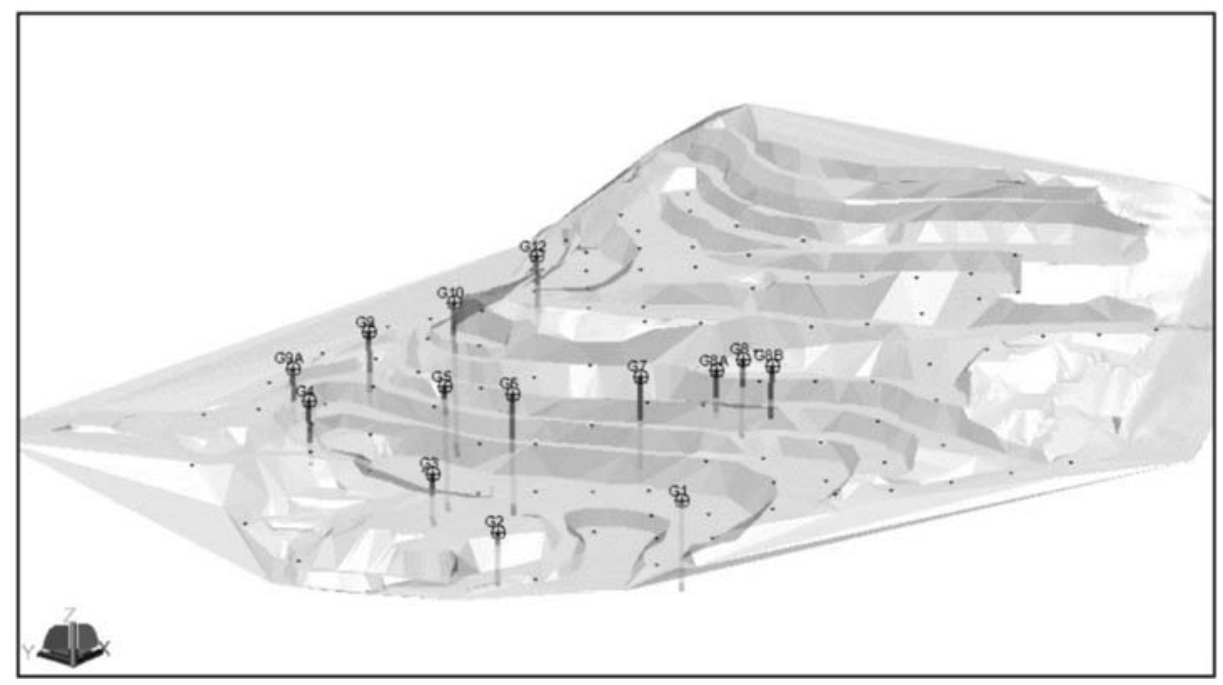

Fig. 3: Digital terrain model of the Altsi Open Pit (transparent), with existing exploration drillholes and surface sampling locations.

\subsection{D Geological modelling}

Computer-aided deposit modelling comprises the generation of a geometric model, a property model, as well as a mine model. A more detailed description of the modeling process in mining can be found in Prissang et al. (1996; 1999). In the model which was set up for this study, the following data were integrated (Fig. 3): a) digital terrain models of the pit surface and the future final exploitation surface area, b) results of the geochemical analysis of 100 surface spot samples located on a $40 \mathrm{~m}$ orthogonal raster and c) 255 samples of drilling cores with an average length of $3 \mathrm{~m}$ each, from exploration drillholes (843m total length). The drillholes were conducted by the company in 1982, whereas the spot sampling took place during this study. The interpretation of all the geochemical data was the base of the lithological description. The latter was processed with the Surpac Vision mining software package in order to setup the model.

\subsection{Geostatistical Structure Analysis}

A geostatistical structure analysis was carried out to investigate the spatial correlation of the grade values concerning $\mathrm{CaSO}_{4}$ and $\mathrm{CaSO}_{4}+2 \mathrm{H}_{2} \mathrm{O}$. These spatial correlation structures can be interpreted as the results of the formation process of the deposit. Empirical variograms indicating the presence of a spatial correlation have been calculated for these parameters. By calculating variogramms for the two parameters, anisotropy ellipsoids for the spatial correlation of the grades could be modeled (Table 1). The best variogramms were obtained in the vertical direction (Fig. 4).

\subsection{Property Modelling}

The objective of property modelling is to provide predictions of the spatial distribution of grade values within the deposit. This covers discretisation of the geological body under consideration, grade estimations as well as reliability checks of the results. 


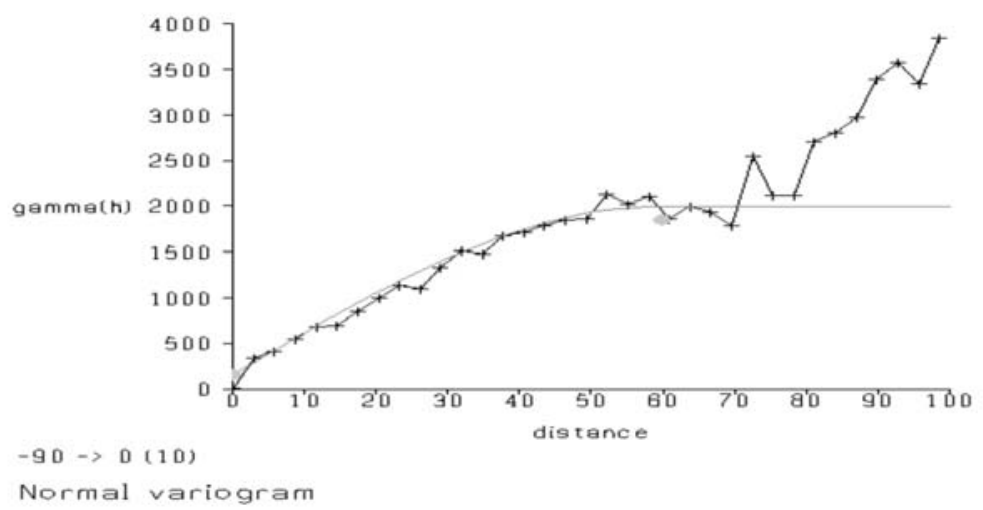

Fig. 4: Variogramm for gypsum in the vertical direction.

Table 1. Parameters of the 3-axis anisotropy ellipsoids for gypsum and anhydrite.

\begin{tabular}{|l|c|c|}
\hline \multicolumn{1}{|c|}{ Parameter } & Gypsum & Anhydrite \\
\hline Direction/Dip of major Axis & N190/04 & N190/-20 \\
\hline Major axis rotation & 0 & 0 \\
\hline Major / Semi-major axis & 1,27 & 1,05 \\
\hline Major / minor axis & 2,10 & 3,33 \\
\hline Maximum Range & $110 \mathrm{~m}$ & $130 \mathrm{~m}$ \\
\hline Vertical range & $40 \mathrm{~m}$ & $60 \mathrm{~m}$ \\
\hline C (nugget) & 60 & 20 \\
\hline Sill & 810 & 970 \\
\hline
\end{tabular}

\subsection{Spatial Discretization}

The representation of the spatial distribution of grade values required the subdivision of the gypsum/anhydrite body into cells. From the point of view of the planning engineer, a block size $3.5 \mathrm{~m} \times 3.5 \mathrm{~m} \times 15 \mathrm{~m}$, matching the size of future extraction units (i.e. blasting blocks), was considered as sufficient. For each block, the grade values had to be computed.

\subsection{Grade Estimation}

The grades for gypsum and anhydrite for the blocks were calculated by the Ordinary Kriging Method. The variogramm models described in Table 9 were used during the estimation, and the anisotropy ellipsoids were also used as search ellipsoids for the estimation procedure. The applied parameters were crossvalidated on the sampling location, to check for possible bias on the estimation results. The estimation error distribution for anhydrite shown on Figure 5 indicates that no bias is inserted in the estimations. The results for gypsum are similar.

The estimated concentrations for gypsum can be seen on Figure 6. 


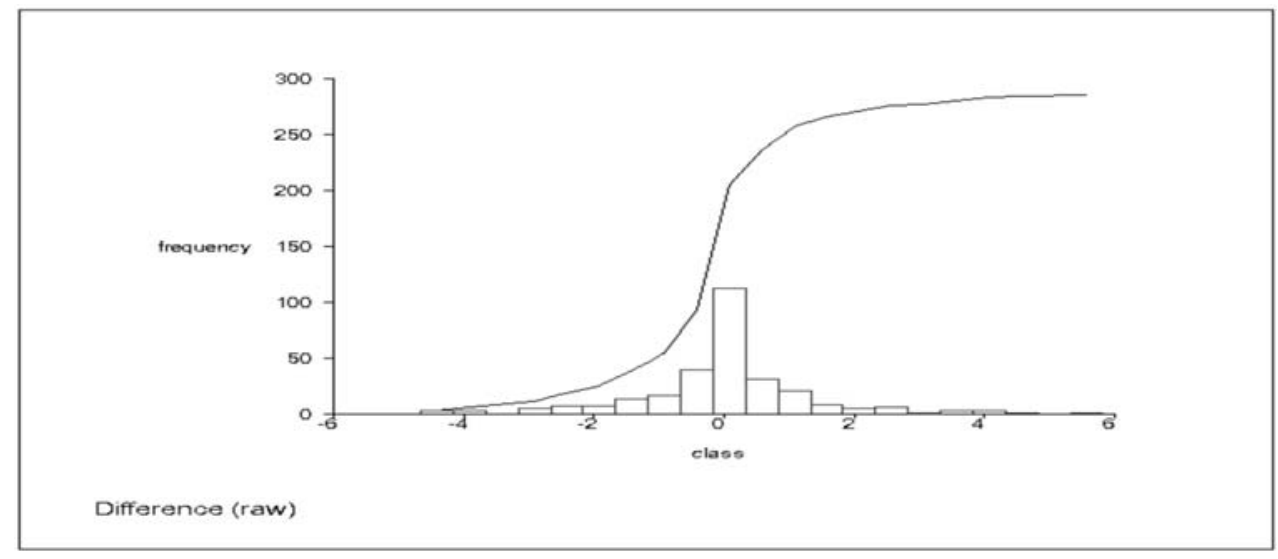

Fig. 5: Estimation error (measured - estimated) for the anhydrite concentrations.

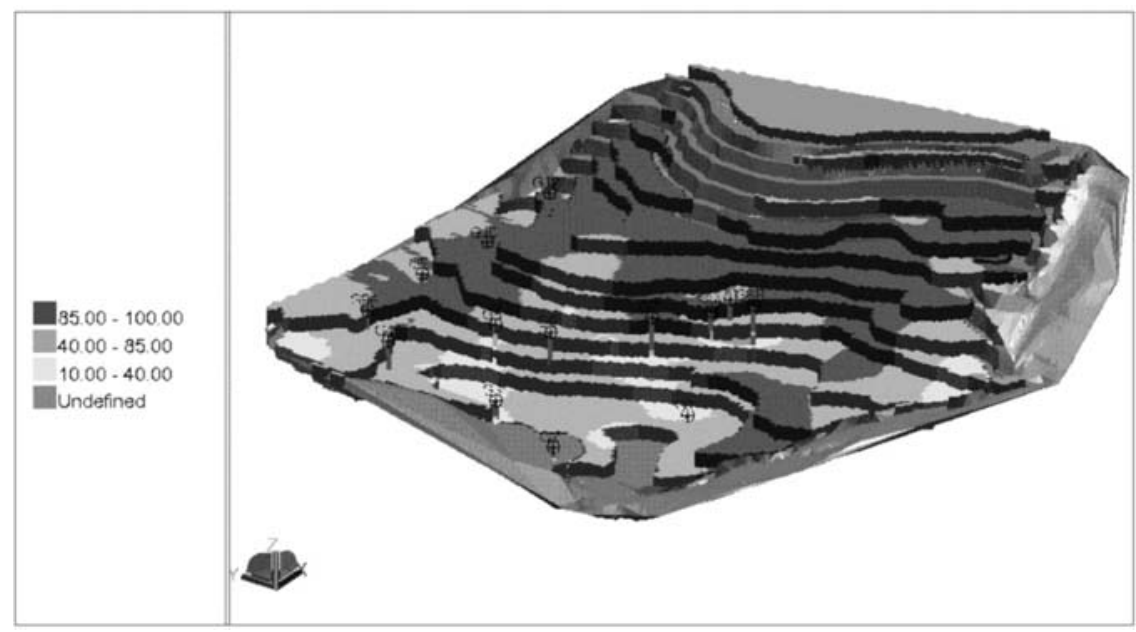

Fig. 6: Block model of the Altsi Open Pit with estimated gypsum values.

\section{Conclusions-Results}

In order to improve further the precision of the outcomes, 5 exploration scenarios are proposed. Results from the old exploration drillholes and from surface sampling are combined in these scenarios. The usual total depth for each sampling position is $25 \mathrm{~m}$ (unless it is stated as less) and the length of each separate sample is $3 \mathrm{~m}$. This option is proposed in order to increase the density of the known spatial information without increasing the total cost of the project. All the proposed scenarios focus on the areas where there is lack of samples/data and, in addition, appear to have the maximum thickness of recoverable material. The drillholes' maximum depths don't exceed the designed final excavation depth of the open pit. As the variogram's vertical range is $40 \mathrm{~m}$ for the anhydrite and $60 \mathrm{~m}$ for the gypsum, drillholes can be limited at a higher elevation. Regarding the assessment of the spatial distribution of the qualities in the pit, based on the results of the structural geostatistical analysis and, in specific, the $60 \mathrm{~m}$ range for the gypsum and the more than $40 \mathrm{~m}$ range for the 
anhydrite in the horizontal dimension, the distance between the drillholes is approximately $120 \mathrm{~m}$ apart. The distance is the same between the new and the existing drillholes. This option contributes to the maximum coverage of the pit's surface area.

From another point of view, if the aim is focused solely on the improvement of the assessment's precision, then some of the new drillholes must be located in a distance of $40 \mathrm{~m}$ from the existing ones and between them. This option contributes to the calculation of new variograms and to the redetermination of the anisotropy's ellipsoid.

Because of the fact that the two aforementioned options have different purposes, different scenarios are proposed. All of them maintain the research's cost in acceptable level. These are:

Exploration scenario 1: 5 drillholes, with a total length of $250 \mathrm{~m}$, or 4 drillholes, with a total length of $280 \mathrm{~m}$

Exploration scenario 2: 3 drillholes, of $194 \mathrm{~m}$ in total length

Exploration scenario 3: 2 drillholes, of 120m in total length and 19 additional surface samplings

\section{Exploration scenario 4: 37 surface samplings}

Exploration scenario 5: 4 drillholes, with a total length of $250 \mathrm{~m} \&$ and 28 supplementary surface samplings

The first two scenarios offer the most insight in the deeper parts of the quarry, but do not offer any improvement in the recognition of smaller intermediate structures than the ones detected by the surface sampling on the $40 \mathrm{~m}$ raster

The $3^{\text {rd }}$ scenario tries to combine knowledge from the deeper parts with the advantages of additional surface information from a more dense raster.

The $4^{\text {th }}$ scenario focuses on the extra information from a surface raster, assuming that the information from the older drillholes concerning the deeper parts of the ore body is sufficiently enough.

Finally scenario 5 maximizes information gain both in depth and on the surface raster.

Scenario number 1 was finally selected as the best candidate, because it offered more information concerning the deepest parts of the ore body. As a result, 4 drillholes were drilled with a total drilling length of $297 \mathrm{~m}$.

After the cumulative evaluation of the total data occurred during the above mentioned new drilling project in combination with the already existing information from the older drilling and sampling campaigns, it became obvious that:

1. The data occurred from the proposed drilling scenarios were crucial not only for the final calculation of the recoverable gypsum reserves, but also for the calculation of the spatial distribution of gypsum and anhydrite in the ore body.

2. As a further consequence of the above mentioned improvements, these information can be considered as really important for the annual planning of the open pit production, since the main aim of the production (concerning the cement factories feeding with gypsum) is focused on providing a stable and predictable quality of raw material (ratio between gypsum/anhydrite), and keeping at the same time the productive benches fully operational and safe. 


\section{References}

Antoniou, M., 1987. Contribution to the knowledge of evaporitic deposits in Eastern Crete and Karpathos islands. Mineral Wealth, 49, 55-62, (in greek).

Cayeux, L., 1902. Sur la composition et l'âge des terrains métamorphiques de la Crète. - C.R.Acad.Sc. Paris, 134, 1117-1119, Paris.

Dornsiepen, U.F., Manutsoglu, E. \& Mertmann, D. 2001. Permian - Triassic Palaeogeography of the external Hellenides. Palaeogeography, Palaoeclimatology, Palaeoecology, 172, 327-338.

Fytrolakis, N., 1980. The geological structure of Crete. Habil. Thesis, NTUA, Athens, 146 pages, (in greek).

Kanaris, I., 1989. Gypsum deposits in the island of Crete, Internal Report IGME, Athens, 63 pages, (in greek)

Nikolaou, K., 1986. Contribution to the knowledge of Neogene and of Geology and delineation of Ionian and Pre-Apoulian zones in relation to petroleum-geological observations performed in the islands of Strofades, Zante, Kefallinia. PhD thesis, University of Athens, 228 pages, (in greek).

Papastamatiou, I., 1958. Report regarding Altsi gypsum deposit in Eastern Crete, Internal Report IGME, Athens, 3 pages, (in greek).

Prissang, R., Spyridonos, E. \& Frentrup, K.-R., 1999. Computer assisted 3D Modelling and Planning for the Cement Industry of El Salvador, Mathematische Geologie, 4, 61-72, Dresden.

Prissang, R., Spyridonos, E., Frommer, Th., Skala, W., 1996. Operational Grade Modelling at the Breitenau Magnesite Mine. In : RAMANI, R.V. (ed.): Proceedings of the 26th Int. Symp. Applications of Computers and Operations Research in the Mineral Industry, APCOM '96, University Park, PA.

Raulin, V., 1869. Description physique de l'ile de Crete. Actes. Soc. Linn. Bordeaux, T.23, pp. 1-157, 321-444, Bordeaux.

Trappe, Jorg, 2000. Pangea: extravagant sedimentary resource formation during supercontinent configuration, an overview. Palaeogeography, Palaeoclimatology, Palaeoecology, 161, 35-48.

Warren, John, 2006. Evaporites: Sediments, Resources and Hydrocarbons, pp. 1036, Berlin etc. (Springer). 